\title{
Symbolism and National Identity in Carl Durheim's Photographic Work
}

\author{
di Sara Romani \\ sromani@alumni.massart.edu
}

\begin{abstract}
In this article I explore the work of Carl Durheim (1810-1890) as a production of highly symbolic imagery geared toward the visual creation of the Swiss national identity in the wake of the establishment of the Confederation in 1848. After providing some background about Durheim and the early history of photography in Switzerland I focus on Durheim's pictures of the so-called Heimatlose (vagabonds), which were commissioned by the Police and Justice Department in Bern. I argue that these pictures cannot be interpreted merely as mug shots taken in order to reproduce the identity of the depicted subjects; rather, using the rhetorical force of photography, these images projected onto the Heimatlose the ideal of the new Swiss society, based on bourgeois values and clearly demarcated from everything foreign through an idealized operation of drawing geographical and social borders.
\end{abstract}

Keywords: Switzerland, Symbols, Portrait Photography, Clothing

Carl Durheim's portrait production offers a unique perspective on the rhetoric employment of iconographic symbols used by the élite of midnineteenth century Switzerland.

This article explores the commission undertaken by the photographer and lithographer Carl Durheim (Bern 1810-1890) for the Police and Justice Department of Bern between 1852 and 1853. The case study offers a successful example of how portraiture and photography were used in the service of the emerging modern state and how iconography was geared to its needs to guide the social body toward the formation of national identity.

My goal is to show that the iconography used to portray a peculiar segment of Swiss society represents one among many rhetorical usages of symbols deployed by the cultural and political elites in order to promote the visualization of national identity. 


\section{Who was Carl Durheim?}

Carl Durheim (Bern, 1810-1890) was a Swiss draftsman, who successfully introduced the photographic technology within his business activity in Bern after receiving an education as typographer and lithographer in Paris (18271828). Durheim travelled all over Europe with the aim of establishing his own activity as a lithographer; he had encountered enthusiasts engaged with the photographic process as well as unsuccessful attempts to fix the latent image: he hesitated to learn the process in light of the poor quality of the images he saw $^{1}$; only later, in 1845 , despite the general euphoria for the French invention, which had already reached his hometown Bern thanks to the work of traveller photographers ${ }^{2}$, Durheim foresaw a business opportunity for his already on-going lithographic atelier. From that time on, he no longer doubted the potential of photographic images and he is today considered among the pioneers in the early history of Swiss photography ${ }^{3}$. In addition to the celebrative pictures of the local middle-class taken in his atelier, and located at the opposite end of the social spectrum, the anthology of about 220 photographic prints (calotypes as well as albumen prints) collected at the Swiss Federal Archive in Bern portray a group of Swiss itinerants without citizenship $^{4}$, the so-called Heimatlose (Figure 1-2).

\footnotetext{
${ }^{1}$ Unless otherwise noted, all translations from foreign-language sources are my own. «J'ai vu une idée imparfaite de la photographie [...] une papier négative qui il s'effaçait petit a petit [...] Arriver a Paris dans le Mois de Mars 1841 j'y ai vu les premiers Daguerréotypies, mais il me paraissait être si mauvais que je renonçais pour le moment à apprendre cette nouvelle découverte». "I saw an imperfect idea of photography [...] a negative paper that was fading little by little [...] Arriving to Paris in the Month of March 1841 I saw there the first Daguerreotypes, but it seemed to me to be so bad that I renounced for the moment to learn this new discovery». 1. Selbstbiographie 1. Redachtion (French) geschrieben 1874 (v.s. 87), Mss.H.H.LII 98, Buergerbibliothek, Bern, pp. 28, 47- 48.

2 B. Giger, P. Stämpfli, D. Di Falco (hrsg.v.) Carl Durheim - Wie die Fotografie nach Bern kam, Collection Passepartout (7), Burgerbibliothek Bern, Bern 2016.

3 U. Tillmanns, Geschichte der Fotografie: ein Jahrhundert prägt ein Medium, Frauenfeld, 1981.

${ }^{4}$ Due to the economic crisis of the 1840s the social phenomenon of itinerancy encompassed many disparate social and cultural condition: for some, such as the Yenish population the itinerancy represented a cultural expression and a lifestyle, for others, such as unemployed and homeless, vagabondage was necessitated by condition of extreme poverty.
} 


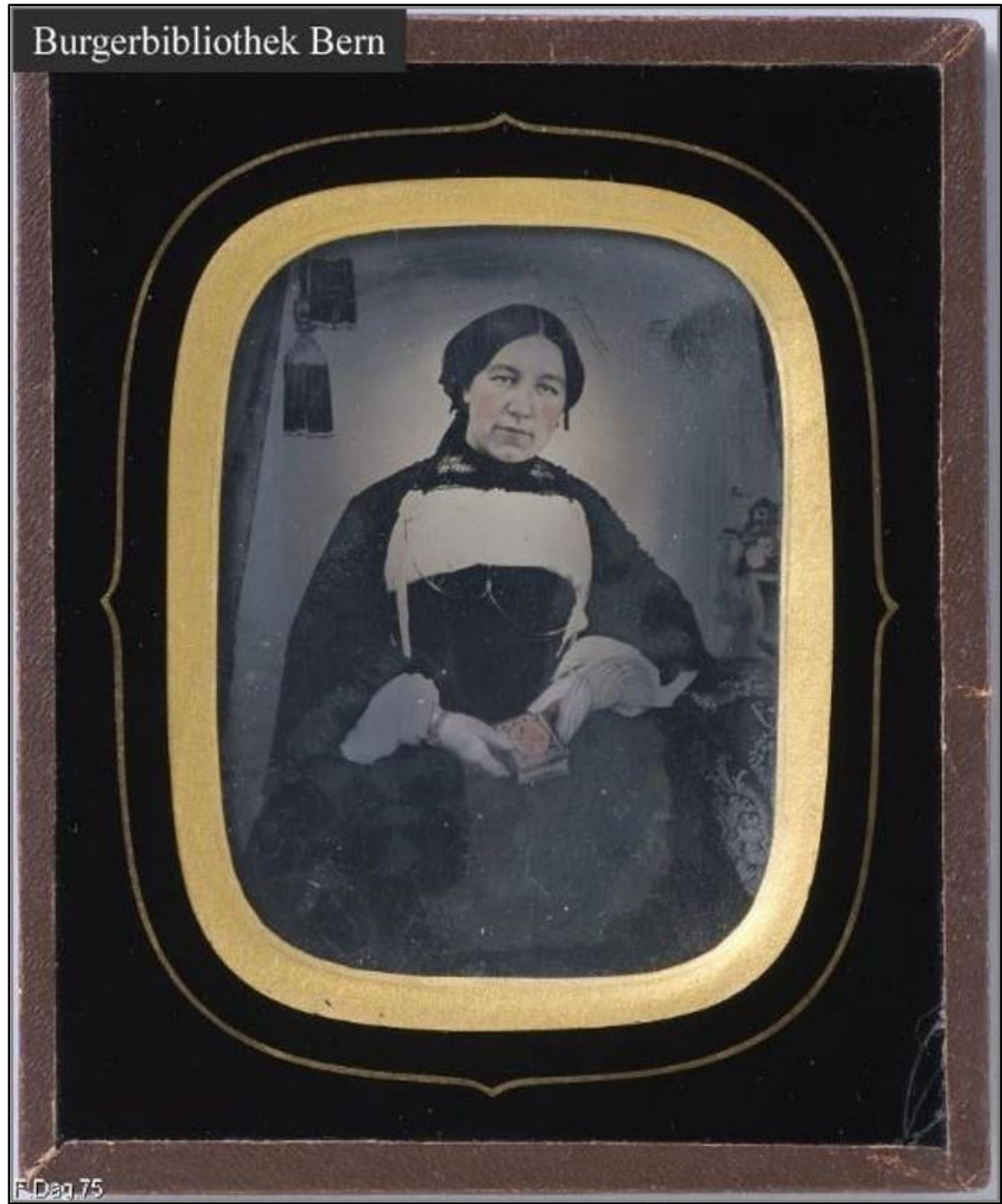

Figure 1: Carl Durheim, Portrait, anonym, between 1852-1890, ambrotype, 9,1 x 7,3 cm, Burgerbibliothek Bern. 


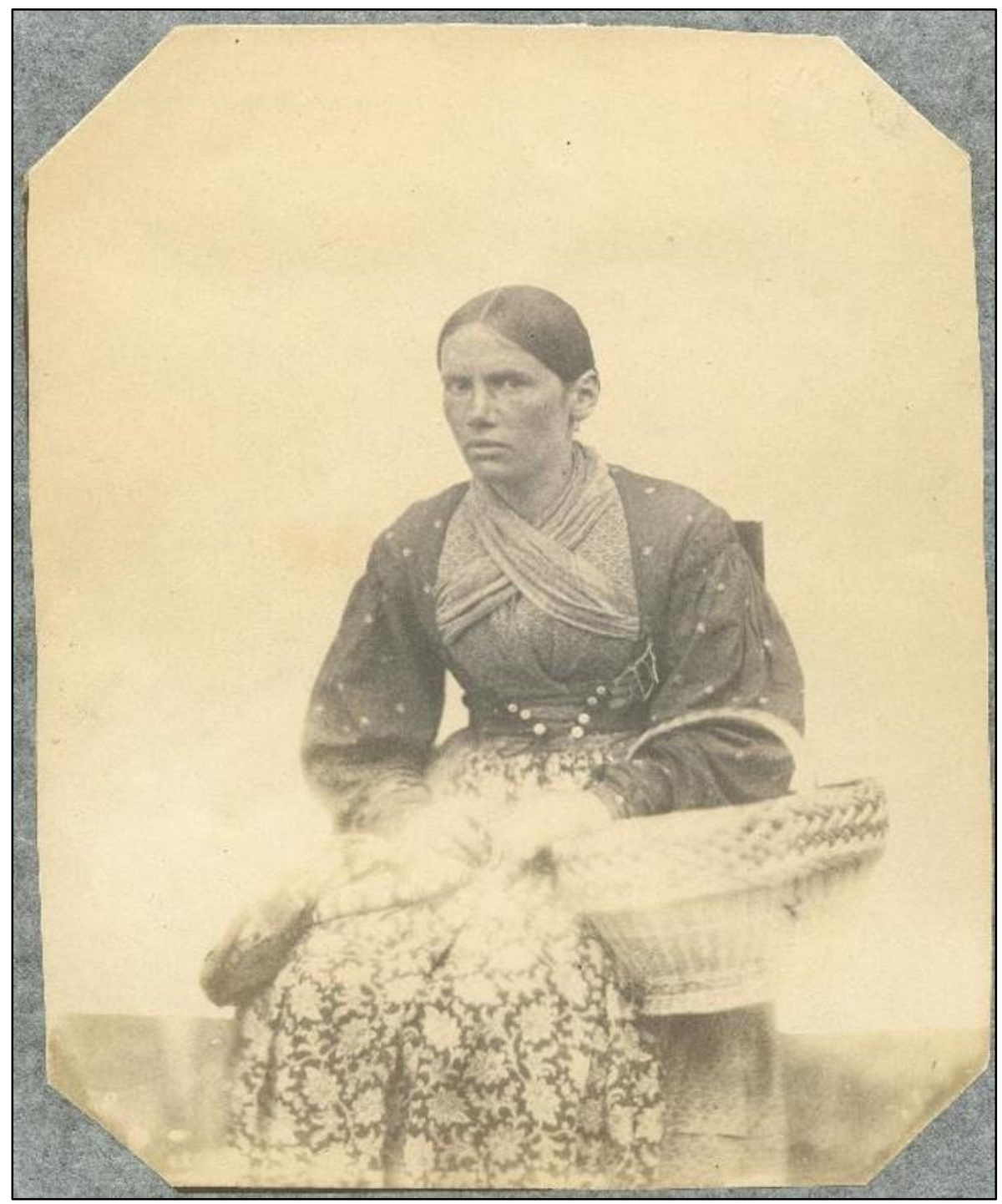

Figure 2: Carl Durheim, Wächter, Katharina Josephine, alias Katharina Josephine Wagner, vulgo Hopsapudels, Salzpapier, 14.5 x 19 cm, between 1852-1853, Swiss Federal Archive, Bern, Signatur: E21\#1000/131\#20507\#195*. 
Such archival material is considered among the first of its genre due to its systematic and standardized form, which makes it fit in the field of police photography ${ }^{5}$. In addition, it represents a unique ethnographic compendium, since it includes one of the first documentation of the Yenish population travelling across the Swiss borders ${ }^{6}$. The uniqueness of these pictures lends itself to be considered as one of the first examples of the utilization of the photographic image as a surveillance instrument 7 . In spite of the beauty and uniqueness of Durheim's photographs, it is necessary to underline that they are a relevant case study, but not an isolated one: the use of photography as a surveillance instrument run parallel to the demand for the visualization of the social norm and its counterpart (the deviation), which must be placed in a historical and social context that does not confine within the Swiss borders and which entwined with the concernment of methods of observing and visualizing natural phenomena. The social world appeared as one of the many fields, where statistical measures and mathematics could be applied: French statisticians, such as M.A. Quetelet and A.A. Cournot exploited the mathematical norm to describe society in 1830 s and 1840 s, to mention one among many examples ${ }^{8}$. From such researches, measurements and

\footnotetext{
5 Beside early similar uses are documented in France and Belgium. See W. Beese, "Zur Geschichte der Polizeifotografie", Kriminalistik, XVIII/11, 1964, pp. 539-550; S. Regener, "Ausgegrenzt. Die optische Inventalisierung des Menschen in Polizeiwesen und in der Psychiatrie", Fotogeschichte, XXXVIII, 1991, pp. 23-38; C. Phéline, L'image accusatrice, Laplume: ACCP, France 1985; J. Jaeger, "Police and Forensic Photographic", in R. Lenman, A. Nicholson (ed. by), Oxford Companion to the Photograph, Oxford University Press, Oxford 2005, pp. 507-510; S. Pearl, About Faces: physiognomy in Nineteenth-Century Britain, Harvard University Press, Cambridge Massachusetts 2010; A. Maxwell, Picture Imperfect: Photography and Eugenics, 1870-1940, Sussex Academic Press, Brighton 2008.

${ }^{6}$ The term Yenish generally refers to a European population, whose principal characteristics are the itinerant lifestyle and a specific language. Hardly tolerated already in $16^{\text {th }}$ and $17^{\text {th }}$ century, they have been persecuted during the $18^{\text {th }}$ and $19^{\text {th }}$ century (and the $20^{\text {th }}$ century). See P. Hugger (hrsg. v.) Handbuch der schweizerischen Volkskultur, Offizin, Zürich 1992; T. Huonker, Fahrendes Volk-verfolgt und verfemt, Jenische Lebensläufe, Limmat Verlag, Zürich 1987.

${ }^{7}$ M. Gasser, T. D. Meier, R. Wolfensberger (hrsg. v.), Wider das Leugnen und Verstellen, Carl Durheims Fahndungsfotografien von Heimatlosen 1852-1853, Offizin Verlag, Zürich 1998.

8 See the phenomenon of the Irish Travellers: J. Helleiner, Irish Travellers. Racism and the Politics of Culture, Toronto University Press, Toronto-Buffalo-London 2000.
} 
classifications entered preponderantly into the study of human being with particular consequences when it came to describe the individual and social behavior. Such interest (i.e. in depicting both appearance and inner character or inclination) was widespread in Europe and beyond ${ }^{9}$. In regard to the representational power of photography in the service of social sciences, anthropology and photography might be seen as two related practices performing in the same timeframe, sharing contentions and critical concerns ${ }^{10}$.

\section{The historical and juridical contextualization of the commission undertaken for the Police and Justice Department of Bern}

In November 1852 Carl Durheim signed a contract with the Advocate General Jakob Amiet, in office for the Federal Council, stipulating that the photographer «undertakes the responsibility to photograph the vagabonds under investigation [...]» ensuring the likeness expected and that the portraits that would not achieve sufficient resemblance would be redone and delivered to Amiet11 (Figure 3).

\footnotetext{
${ }^{9}$ A. Sekula, "The body and the Archive", October, xxxIx, 1986, pp. 3-64; H. K. Henish, B. A. Henish, The Photographic experience 1839-1914: Images and attitudes, Pennsylvania State University Press, University Park 1994; J. Ellenbogen, Reasoned and Unreasoned Images: The Photography of Bertillon, Galton and Marey, Pennsylvania State University Press, University Park 2012; G. Moser, Projecting Citizenship: Photography and belonging in the British Empire, Pennsylvania State University Press, University Park 2019; J. R. Ryan, Picturing Empire: Photography and the Visualization of British Empire, University of Chicago Press, Chicago 1998.

${ }^{10}$ A digression on the parallel historical development of anthropology and photography would far exceed the scope of the present essay. In this regard see Christopher Pinney's and Justine Carville's recent researches: C. Pinney, Photography and Anthropology, Reaktion Books, London 2011; J. Carville, "Photography, Ethnography and Cultural Nationalism in Northern Ireland", in C. Caraffa, T. Serena (ed. by), Photographic Archives and the Idea of Nation, De Gruyter, New York-Berlin, 2015, pp. 17-42; J. Carville, "A Geographic Fact: Photography, Ethnography and History in Ireland", in T. Sheehan (ed by) Photography, History, Difference, Dartmouth College Press, Lebanon New Hampshire 2015, pp. 11-32.

${ }^{11}$ Swiss Federal Archive, CH-BAR\#E21\#1000-131\#20528\#5, Verschiedene Korrespondenzen zu den Photographischen Bilder der Heimatlosen (1852-1853).
} 


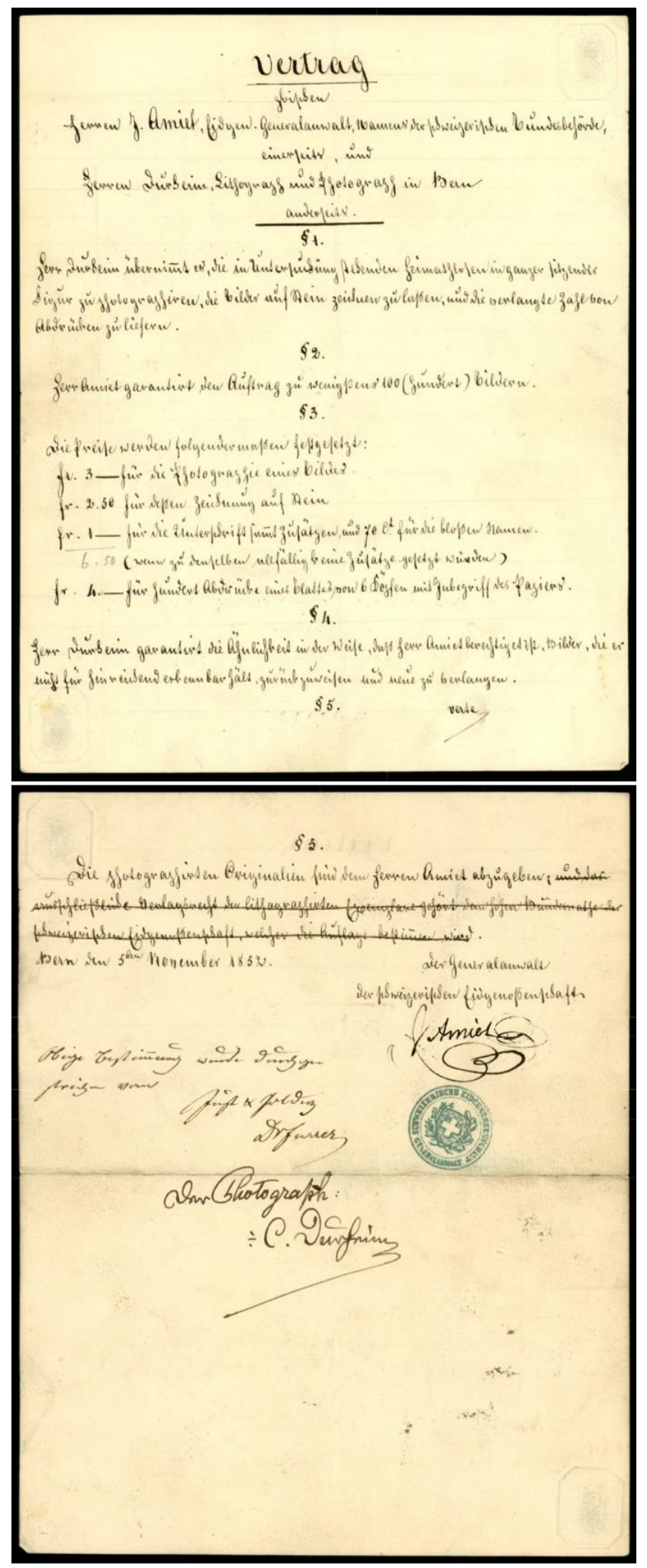

Figure 3: Verschiedene Korrespondenzen zu den Photographischen Bilder der Heimatlosen, 1852, Vertrag, CH-BAR\#E21\#1000-131\#20528\#5\#8, Swiss Federal Archive, Bern. 


\section{Vertrag \\ zwischen}

Herrn J. Amiet, Eidgen. Generalanwalt, Namens der schweizerischen Bundesbehörde, einerseits, und

Herrn Durheim, Lithograph und Photograph in Bern anderseits.

$\S 1$.

Herr Durheim übernimmt es, die in Untersuchung stehenden Heimathlosen in ganzer sitzender Figur zu photographiren, die Bilder auf Stein ziehen zu laßen, und die verlangte Zahl von Abdrücken zu liefern.

$\S 2$.

Herr Amiet garantiert den Auftrag zu wenigstens 100 (Hundert) Bildern.

$\S 3$.

Die Preise werden folgendermaßen festgesetzt:

Fr. 3 - für die Photographie eines Bildes.

Fr. 2,50 für deßen Zeichnung auf Stein

Fr. 1 - für die Unterschrift sammt Zusätzen, und 70 ct. für die bloßen Namen.

[6,50 nachtr. mit Bleistift ergänzt] (wenn zu denselben allfällig keine Zusätze gesetzt würden)

Fr. 4 - für Hundert Abdrücke eines Blattes von 6 Köpfen mit Inbegriff des Papiers.

$\S 4$.

Herr Durheim garantiert die Ähnlichkeit in der Weise, daß Herr Amiet berechtigt ist, Bilder, die er nicht für hinreichend erkennbar hält, zurückzuweisen und neu zu verlangen.

$\$ 5$.

Die photographierten Originalien sind dem Herrn Amiet abzugeben; und das ausschließliche Verlagsrecht der Lithographierten Exemplare gehört dem Hohen Bundesrathe der schweizerischen Eidgenossenschaft, welcher die Auflage bestimmen wird.

Bern den 5ten November 1852.

der Generalanwalt

der schweizerischen Eidgenossenschaft gez. J. Amiet.

Obige Bestimmung wurde durchgestrichen

Justiz. u. Poldep. gez. [Dr. Furrer]

Der Photograph:

gez. C. Durheim ${ }^{12}$

12 «Contract between Mr. J. Amiet, Confeder. Advocate General, in the name of the Swiss Federal on the one hand, and Mr. Durheim, lithographer and photographer in Bern on the other hand. $\S 1$. Mr. Durheim undertakes to photograph the Heimathlosen under examination in their entire seated figure, to draw them on stone, and to deliver the required number of prints. §2. Mr. Amiet guarantees the order of at least 100 (one hundred) pictures. §3. The 
Taking the phenomenon of nineteenth-century nationalism as the framework for historiographical debate, Carl Durheim's portraiture production provides insights into the role played by portraiture and its iconography in the eyes of Jakob Amiet (1817-1883), Attorney General representative of the new-born Swiss Confederation in the time that immediately follows the political configuration of the liberal modern nation ${ }^{13}$. Although the Sonderbund war established the end of civil fights among cantons of different faith, it ignited an ever-growing interest from the appointed institutions and the leading parties in the definition -and subsequent illustration- of the community's identity ${ }^{14}$. Among European countries characterized by nationalism based on linguistic and cultural homogeneity (i.e. France, Great Britain and Germany), the Swiss intellectuals, authorities and political representatives yearned for flaunting an image of national authenticity although Switzerland was marked by regionalism. The Swiss poet Gottfried Keller, to mention one of the most distinguished intellectuals of international reputation, promoted the idea that the voluntary commitment to a set of political values, the ways of life,

prices are regulated as follows: Fr. 3 - for the exposure of one picture. Fr. 2,50 for its drawing on stone. Fr. 1 - for the caption including supplements, and $70 \mathrm{ct}$. for the mere names. [6,50 added in pencil] (if no additions were made to the same). Fr. 4 - for one hundred impressions of a sheet of 6 heads with epitome of the paper. $\$ 4$. Mr. Durheim guarantees the resemblance in such a way that Mr. Amiet asked for, to print images that he (Amiet) does not consider sufficiently recognizable, to reject them and to demand new ones. $§ 5$. The originals shall be delivered to Mr. Amiet; and the exclusive publishing right of the lithographic copies belongs to the High Federal Council of the Swiss Confederation, which will determine the edition. Bern, November 5, 1852. The Advocate General of the Swiss Confederation, Signed J. Amiet. The above provision was crossed out Justiz. u. Police Dep. Signed [Dr. Furrer]. The photographer: Signed C. Durheim». Verschiedene Korrespondenzen zu den Photographischen Bilder der Heimatlosen, 1852, Vertrag, CH-BAR\#E21\#1000-131\#20528\#5\#8, Swiss Federal Archive, Bern.

13 T. Maissen, "The 1848: conflicts and their significance in Swiss historiography", in M. Butler, M. Pender, J. Charnley (ed. by), The making of modern Switzerland, 1848-1998, Springer, New York 2000, pp. 3-35.

${ }_{14}$ The increase of pauperism in the 1830s and 1840s was due principally by two factors: famine and the demographic increase among the population of the countryside. 
the trust of institution and the love of the fatherland would build authentic Swiss citizens ${ }^{15}$.

After the proclamation of the Federal Constitution on September $12^{\text {th }}$, 1848, the two most striking manifestations of such political wave were: 1) the definition of national borders of the modern State 2) and by consequence, the definition of a Swiss national identity based on the right of citizenship. The Homeless Law of 1850 was promulgated to regulate the integration and assimilation of the homeless and non-settled persons. As Meier and Wolfensberger argue:

The importance of the law lay in the standardization of measures and the possibility of subjecting their execution and implementation to central federal control. Moreover, with the Federal Constitution and the Homeless Law, the description of what was to be foreign in the future was also defined from the governing center of Switzerland. A foreigner was anyone who did not possess Swiss citizenship. The border to foreignness was the border of the Swiss nation state $^{16}$.

The rhetoric used by the newborn institutions centered on the encouragement of civil responsibility through an education based on renewed morality ${ }^{17}$. The redefinition of the legal status of groups identified as

15 O. Zimmer, "Coping with deviance: Swiss nationhood in the long nineteenth century", Nations and Nationalism, XVII/4, 2011, pp. 756-774.

16 «Die im Heimatlosengesetz von 1850 vorgesehenen Massnahmen unterschieden sich inhaltlich nicht wesentlich von in den Heimatlosenkonkordaten und kantonalen Gesetzen vorgegeben Strategien zur Integration und Assimilation der Heimatlosen und NichtSesshaften. Auch auf der legitimatorischen und diskursiven Ebene kamen kaum Elemente dazu, die nicht bereits in frueheren Quellen des 19.Jahrhunderts formulieren worden waeren. Die Bedeutung des Gesetzes lag in der Vereinheitlichung der Massnahmen und der Moeglichkeit, deren Vollzug und Durchfuehrung einer zentralen bundesstaatlichen Kontrolle zu unterwerfen. Mit der Bundesverfassung und dem Heimatlosengesetz wurde zudem die Beschreibung dessen, was in Zukunft fremd sein sollte, ebenfalls vom regierenden Zentrum der Schweiz aus definiert. Fremd war, wer kein schweizerisches Staatsbuergerrecht besass. Die Grenze zur Fremdheit war die Grenze des Schweizerischen Nationalstaates». T. Meier, R. Wolfensberger, Eine Heimat und doch keine, Heimatlose und Nicht-Sesshaften in der Schweiz (16.-19.Jahrhundert), Chronos Verlag, Zürich 1998, p. 475.

17 «Das Wohl und Wehe eines Jeden Staates beruhet auf dem sittlichen Werthe seiner Bürger; ohne Bildung des Herzens und des Geistes ist keine Freiheit denkbar und die Liebe zum Vaterland ist ohne sie ein leerer Schall». B. Junker, Geschichte des Kantons Bern Seit 1798, Entstehung Des Demokratischen Volkstaates, Band II, Historischer Verein Des Kantons Bern, Bern, 1990, p. 41. Reading between the lines, the aforementioned petition of December 
homeless or stateless and vagrants aimed at counteracting marginalization from the Swiss economic and civil life. Among the Swiss itinerants without citizenship emerged two different legal statuses: 1) Heimatlose (homeless or stateless) and 2) Vagabonds (vagrants or itinerants). In nineteenth-century Switzerland, the term homeless referred to non-citizens or the so-called "paperless people", who, generally speaking, conducted a nomadic lifestyle. While the term "homeless" referred principally to foreign people, who travelled through the Swiss territory illegally, the term "vagabond" was applied to a non-homogeneous group, which shared a condition of extreme poverty but who were Swiss nationals, moving continuously from town to town, or from farm to farm, in search of seasonal or temporary occupations. They were often identified with the terms "Vaganten", "Vagabunden" or "Landstreicher": they had Swiss nationality, but they were neither permanent residents, nor assigned to a municipality, which means that they were excluded from civil rights and from subsidiary help ${ }^{18}$. In 1848, on the occasion of the proclamation of civil rights for the inhabitants of the country, marginalized social groups finally succeeded in acquiring Swiss citizenship: citizenship and nationality were assigned and fixed to a municipal citizenship (e.g., the city of Bern).

The definition of national borders of the modern State and the definition of a Swiss national identity are two slow processes, characterized by a long duration and not detachable from each other.

1830 had already exemplified the standpoint of the institutions toward the introduction of moral value as one of the main ingredients for the successful education of its citizens. In this context, nomadic lifestyle was positioned at the antithesis of bourgeoisie moral norms. See also: D. Di Falco, "Verfolgt, verhaftet, verhört und abgelichtet", Der Bund, XXXIX, 1998, p. 7. T. Meier, R. Wolfensberger, "Die Bürgerliche Gesellschaft und die Nichtsesshaften", Neue Zürcher Zeitung, XxxIV, 1996, p. 17.

${ }^{18}$ T. Huonker, "Fremd- und Selbstbilder von "Zigeunern", Jenischen und Heimatlosen in der Schweiz des 19. und 20. Jahrhunderts aus literarischen und anderen Texten", in H. Uerlings, I.-K. Patrut (hrsg. v.), Zigeuner und Nation, Repräsentation - Inklusion - Exklusion, Peter Lang, Frankfurt am Main 2008, pp. 311-364. 
The role and definition of the borders of the dwelling place in its primitive sense (the relationship to the territory, its delimitation, the knowledge and the ability of representing it visually) could not be detachable from the formation of the identity understood as that set of characteristics (more or less physical) and values with which one identifies oneself. The definition of spatio-temporal coordinates (i.e.: the measurement of spaces) and their representations entwines with the process of identification: the act of drawing national borders and describing the geography of the country (i.e., the production of maps) meant to outline also (and to represent) the local characters of its inhabitants. In other words, it meant drawing the boundaries within which to shape the identity of individuals.

\section{Portraits and symbols}

When speaking of portraiture as an artistic genre, from the standpoint of the observer who looks at the representation of the likenesses of his/her face, two processes are involved: "projection" (or "vision") and "identification"19. The two terms require an explanation: the first implies to project outside oneself an image of the self, which does not necessarily have to be a realistic one; Hans Belting, in his study on portraiture, states: «Every portrait placed its subject in society, be it in an actual or perhaps a desired position ${ }^{20}$. The subject portrayed in a picture is placed "outside": the subject that looks at the picture of her/himself recognizes her/himself in the representation, which is projected and placed outside her/his body. Generally speaking, in the eye of the person depicted, every portrait embodies a projection of the subject. The second term, "identification", means that the subject depicted identifies her/himself with a picture: it means that she/he internalizes what she/he sees

\footnotetext{
19 See H. Bredekamp, Theorie des Bildakts, Suhrkamp, Frankfurt am Main 2010.

${ }^{20}$ H. Belting, Face and Mask: A Double History, en. tr. by T. S. Hansen and A. J. Hansen, Princeton University Press, Princeton-Oxford 2013, p. 126.
} 
represented (or is located) outside her/himself in the portrait. Identification thus involves recognizing an inner correspondence of part or all of one's identity with what is represented in a picture.

In the existing literature, Carl Durheim is known as the creator of some of the first mug shots in Europe, also known as identification pictures. In nineteenth-century photography mechanical reproduction appeared with its promise to provide visual evidence of the subject's identity. The collection of portraits of the Heimatlose is usually discussed following Foucault's analysis of power: they are taken to epitomize the fledgling power structure of the Swiss modern State ${ }^{21}$. The Foucauldian paradigm lends itself to explaining the use of the photographic portrait as a means of control and the reasons why the appearances of the identification portrait are very similar to those of the studio portrait. From the observer's standpoint, the nineteenth-century is characterized by a continuous arrangement of bodies, which «codified and normalized the observer within rigidly defined systems of visual consumption ${ }^{22}$. From this arrangement of bodies comes a physical accumulation of knowledge about them, which takes concrete shape in photographic prints and albums. Once the exposure was taken, a lithographer had the task of drawing six portraits per page, inserting the generalities of each and binding the plates in albums (Figure 4-5).

${ }^{21}$ W. Beese, "Zur Geschichte der Polizeifotografie", cit. T. Meier, R. Wolfensberger: Eine Heimat und doch keine, Heimatlose und Nicht-Sesshaften in der Schweiz (16.19.Jahrhundert), cit. S. Regener, "Ausgegrenzt. Die optische Inventalisierung des Menschen in Polizeiwesen und in der Psychiatrie", cit.

22 J. Crary, Techniques of the Observer: On Vision and Modernity in the Nineteenth Century, MIT Press, Cambridge-London 1990, p. 18. 


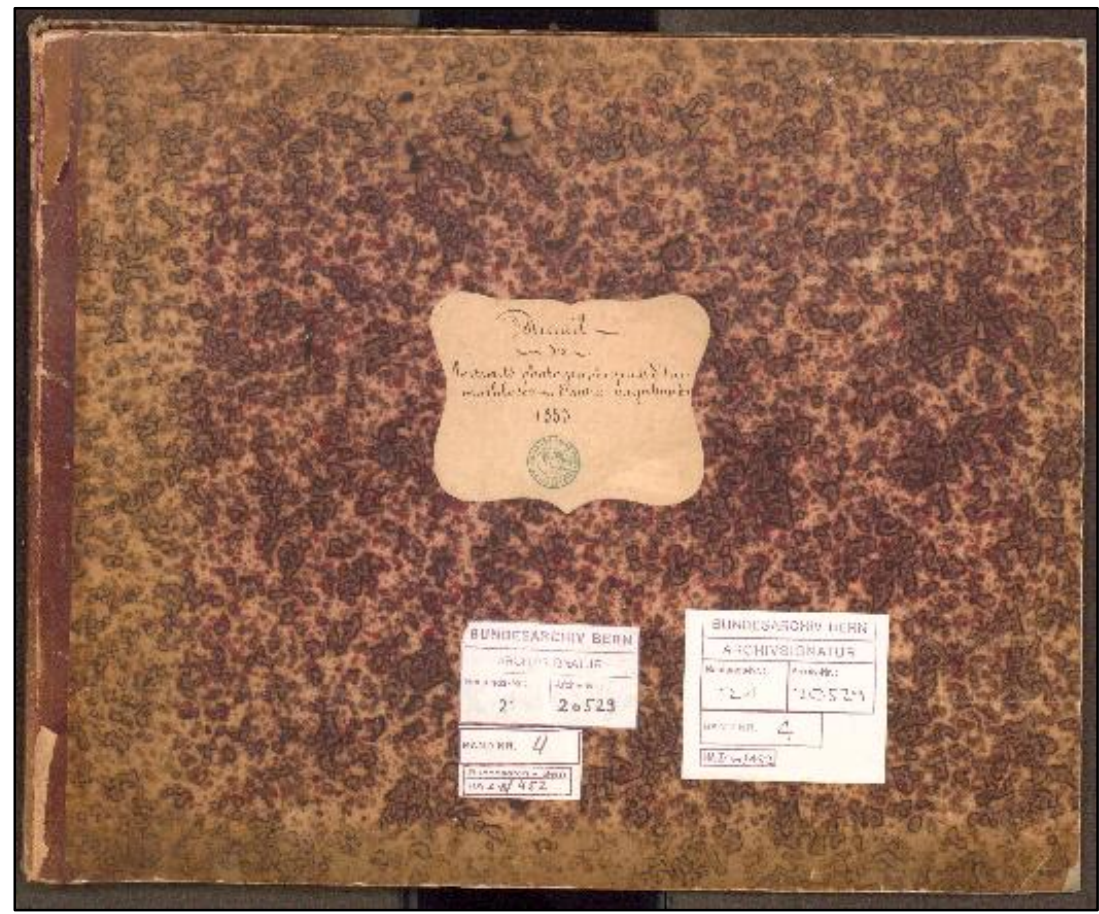

Figure 4: Carl Durheim, Cover: Recueil des Portraits photographiques d'heimathloses ou d'autres vagabonds, E21\#1000/131\#20529*, 1853, Lithograph, Bern, CH-BAR\#E21\#1000-131\#20528, Swiss Federal Archive, Bern.

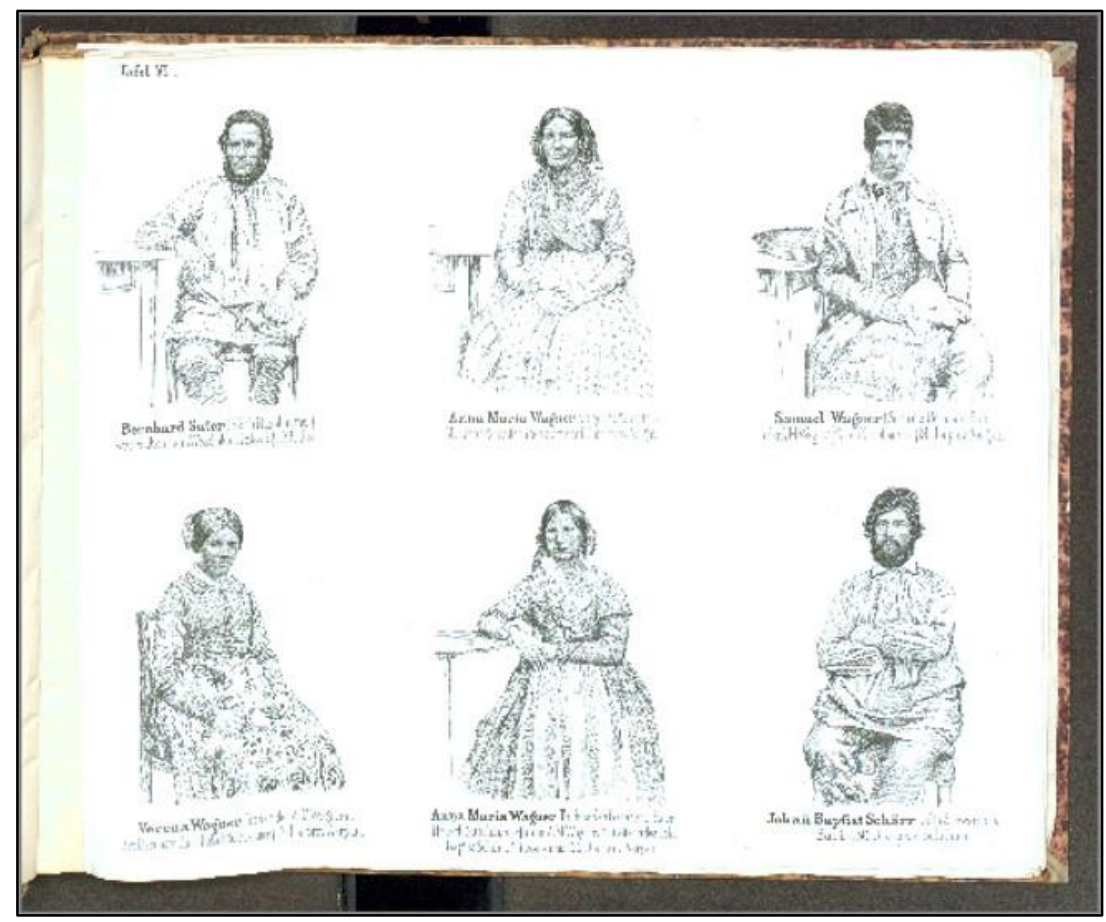

Figure 5: Carl Durheim, Table VI, Recueil des Portraits photographiques d'heimathloses ou d'autres vagabonds, E21\#1000/131\#20529*, 1853, Lithograph, Bern, CH-BAR\#E21\#1000-131\#20528, Swiss Federal Archive 
The photographic portrait functions as a means of control in the hands of the police, which was involved in a wanted search for the Heimatlose. By contrast, most of the itinerants resisted a change in their lifestyle and refused to adapt to bourgeois norms. In this context, photographic technology and the printed photograph can be read as a form of panopticon, where the portrayed subject is scrutinized through the camera. The person portrayed (the prisoner) has no access to the spaces where her/his portrait is stored (police office); unknown people (the institution/the police officer) that she/he cannot see scrutinize her/his portrait. The itinerants felt revealed by the act of being photographed in the courtyard of the prison, so the photographic ritual performs two functions: symbolically speaking, to stay still in front of the camera meant, seated to pose as a bourgeois, was antithetical to their way of living; the camera would fix and reveal their features permanently. In addition, «The pictures were recognized by the vagabonds themselves» ${ }^{23}$. As the report of the Swiss Federal Council to the High Federal Assembly on its management in 1852 states, the Heimatlose had access to their photographs once they were asked to recognize themselves in the pictures. In this sense this group of photographs perform the function of a document, because they record the very voice of the subjects, who admit to identifying themselves represented in the image. If we return to the content of the contract, we can rightly conjecture that the picture was stored in Amiet's personal archive, and we can also conjecture that the appointed institution (i.e. local police officers or cantonal police) used instead the lithographic copies as needed.

Moving past Foucault's philosophical genealogy of power structures and focusing on the iconography of Durheim's portraits, one aspect challenges their interpretation as mug shots and thereby paves the way to another level of image reading: the clothing.

23 «Die Bilder werden von den Heimatlosen selbst erkannt». Swiss Federal Archive, Bundesblatt Nr31 von Juli 1853, Bericht des schweizerischen Bundesrates an die hohe Bundesversammlung über seine Geschäftsführung im Jahr 1852, BB I 1853 II 665, p. 718. 
The prisoners were dressed up as peasants and daily workers for the shot. Peasant clothing was given to the Heimatlose and vagrants in custody. The clothing had a symbolic function: the peasant constitutes the antitype of the traveller. Many of the itinerants appear in the photographs in peasant guise (Bauernkutten) with their normal clothing discernible beneath their peasant vests (Figure 6).

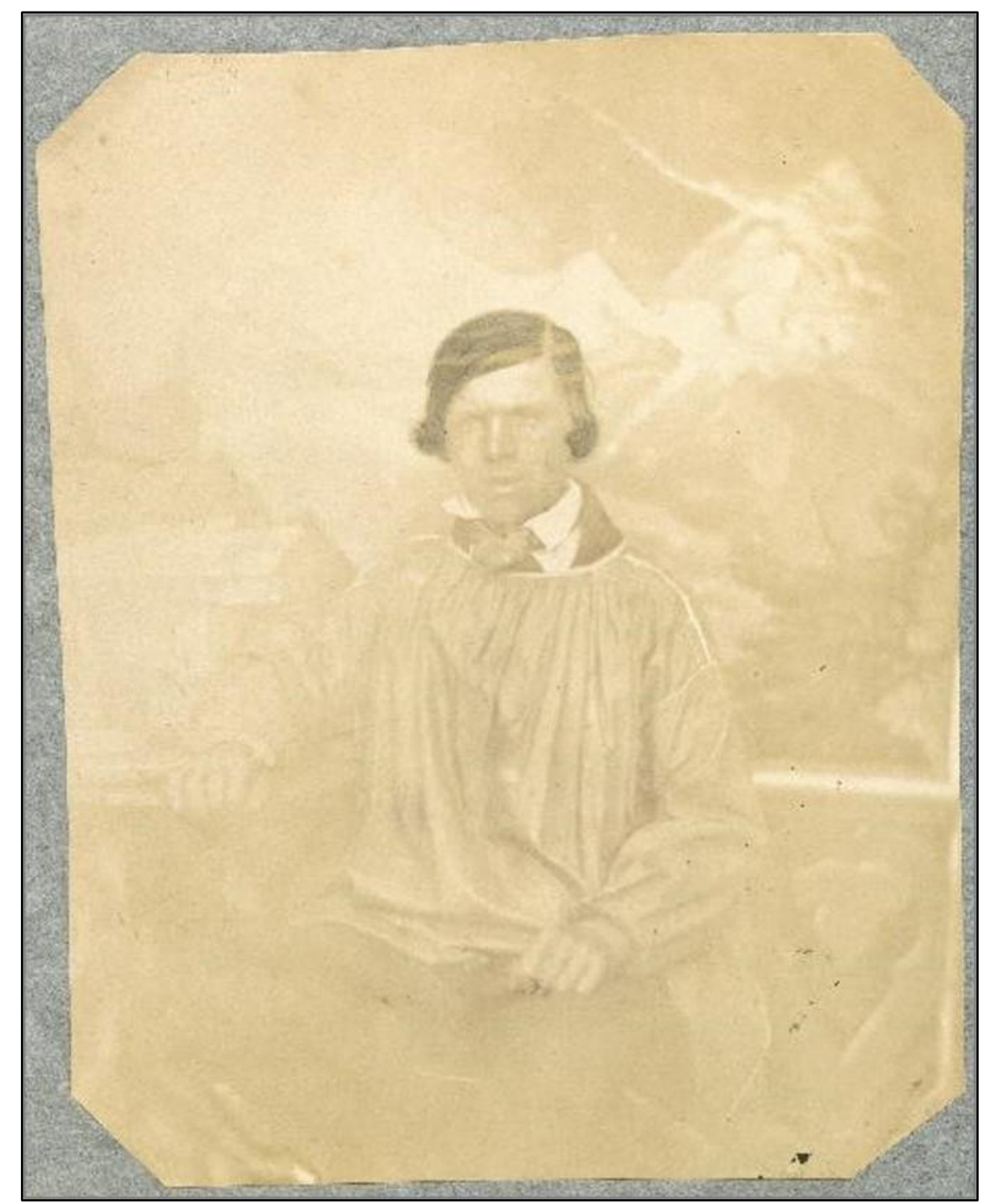

Figure 6: Carl Durheim, Gottfried Fayble, Salzpapier, 14.5 x 18.5 cm, between 1852 and 1853, Swiss federal Archive, Bern, Signatur: E21\#1000/131\#20507\#56*. 
The Advocate General bought the information services of a number of vagrants through recurring gifts of clothing and food, and paid witness fees for useful testimony. Amiet wrote to the attorney's office that it was necessary to procure clothing for the homeless in detention, because «most of whom arrived here wrapped in miserable rags and whose children were usually halfnaked $»^{24}$.

To dress up the prisoner as day laborers (farmers, shepherds) for the photo shoot amounts to a manipulation of their identity. In the field of early medical photography many examples demonstrate how the patient's dress was used to strip the subject of his identity and thus make him a generic body at the service of scientific study. In these studies, the patient's white tunic is used to direct the observer's attention to gestures or expressions of the body and face, as documented in the photographs of Dr. Duchenne de Boulogne ${ }^{25}$. On the contrary, for the bourgeois to pose in front of the camera had a meaning in line with the primary function of the portrait, that is, to show his or her physical and ideal identity. Bourgeois portrait validated a social identity thanks to the display of clothes and objects carefully chosen and repeatedly appearing in the pictures as shared signs of social belonging. The action of dressing up prisoners distances these portraits from the function of being exclusively images for police identification, precisely because one of the aims of the operation was to establish their identity on a twofold layer: the institutions asked these people to declare once and for all an identity that would establish for them simultaneously both the peculiarity of their physiognomic appearances and a geographical and social location. On the contrary, photographic documentation of scientific studies (such as the one produced by Duchenne Du Boulogne to mention one example) aimed at

${ }^{24}$ T. Meier, R. Wolfensberger, Eine Heimat und doch keine, Heimatlose und Nicht-Sesshaften in der Schweiz (16.-19.Jahrhundert), cit., p. 478.

${ }_{25}$ See G.-B. Duchenne de Boulogne, Mécanisme de la physionomie humaine ou analyse électrophysiologique de l'ex- pression des passions, Renouard, Paris 1862. 
producing the visualization of data, they worked as proof of scientific statements ${ }^{26}$.

For whom do Durheim's portraits perform the function of identification? To answer the question, it is necessary to move to a different theoretical framework than the one based on the power-body-surveillance triad ${ }^{27}$. In the collective imagination, identification pictures - the common mug shot - play the role of documenting the identity of the portrayed subject; in other words, they prove the authenticity of an identity. By contrast, Durheim's identification photographs prove an imagined identity ${ }^{28}$, which does not affect the generalities (first name, last name, place and date of birth, possibly paternity) that determine the factual identity of the individual. Imagined identity -being peasants and workers- plays out at the level of the individual's dislocation in society. Durheim's identification pictures do not only prove the authenticity of the identity of the portrayed subject; they also reveal that political institutions and their representatives had a very specific ideal of society within which to place a certain segment of the population. As Martin Gasser explains:

By dressing them up as peasants, the outward appearance of the photographed people was manipulated, too. The homologating clothing, the choice of objects, the mise-en-scène and partly the editing work, whose sometimes sloppy execution shows the serial character of the task, which had to be carried out as cheaply as possible, neither mirror the praxis of life, nor do they convey a faithful picture of the photographed people ${ }^{29}$.

${ }^{26}$ See also H. W. Diamond, On the Application of Photography to the Physiognomic and Mental Phenomena of Insanity, Proceedings of the Royal Society of London (1854-1905), 1856, p. 117.

27 J. Tagg, The burden of representation, Essays on Photographies and Histories, The University of Massachusetts Press, Amherst 1988.

28 See B. Anderson, Imagined Communities. Reflections on the Origin and the Spread of Nationalism, Verso, London-New York 1991.

${ }^{29}$ M. Gasser, Wider das Leugnen und Verstellen, Carl Durheims Fahndungsfotografien von Heimatlosen 1852-1853, cit., p. 18. 
While Foucauldian analysis examines the semiotic and iconographic level of the image, I suggest to introduce a reflection on the material form of these images and their physical nature as objects, as extensively discussed by Elisabeth Edwards in regard to the analysis of ethnographic photographs ${ }^{30}$. As the aforementioned report of the Swiss Federal Council to the High Federal Assembly on its management in 1852 states, the Heimatlose looked at the photographs and they were asked to recognize themselves in the pictures. Such handling of the picture shifts our analysis to another interconnected field of inquiry, which regards the material form of images ${ }^{31}$. The authorities judged the first specimens of images with these words: «the collection promises to be thoroughly characteristic and interesting» ${ }^{32}$. Why do federal board officials judge the portraits to be «characteristic and interesting»? From what perspective does the board look at the portrait collection? In other world, the attention of the authority was not only focused on what was represented in one single picture, but they judged the collection as a whole, as a group of images, as an archive.

The identification photographs of the Heimatlose are not only used by police; their function as images goes beyond the prerogatives of the judicial system, since the discourse that surrounds them is about the reorganization of mid-nineteenth-century Swiss society. The photograph is judged "interesting" in the context of a collection of photographic portraits: the single image acquires its meaning within the group of pictures, as the single identity

\footnotetext{
${ }^{30}$ E. Edwards, "Material beings: Objecthood and ethnographic photographs", Visual Studies, XVII/1, 2002, pp. 67-75; G. Batchen, Photography's Objects, University of New Mexico Press, Albuquerque 1997.

31 «The archive becomes a material manifestation of social relations in which images are active». E. Edwards, "Photographs: Material Form and the Dynamic Archive", in C. Caraffa (ed. by), Photo Archive and the Photographic Memory of Art History, Deutcher Kunstverlag, Berlin 2001, p. 49.

32 «Die Sammlung verspricht durch und durch charakteristisch und interessant zu warden». Schweizerisches Bundesarchiv Bern, CH-BAR E 211000-131205281, Verschiedene Korrespondenzen zu den Photographischen Bilder der Heimatlosen (1852-1853).
} 
of the itinerant gains full recognition within the community (Gemeinde) ${ }^{33}$. The reorganization of society is also accomplished through its visualization (to make it visible, to show it) by images. Carl Durheim's photographic portraits of the itinerants are, in this sense, symbolic representations.

«Under a "symbolic form" should be understood each energy of spirit [Geist] through which a spiritual [geistig] content or meaning is connected with a concrete, sensory sign and is internally adapted to this sign ${ }^{34}$.

Ernst Cassirer defines the symbolic form as consisting of two elements, i.e. the immaterial part of meaning and the tangible or concrete form. The symbolic meaning needs a physical body (sensory sign) to be perceived. The ideal of sedentary life needs the physical bodies of the itinerants clothed as peasants to be visually perceived, as well as the ideal of the Swiss nation as modern state needs the physical borders traced on a map to be visualized by its citizens. In his introduction to the study of the topography of Switzerland, the historians David Gugerli and Daniel Speich state that: «nationalism as an engine of political processes only works when the individual members of the evoked community feel part of this whole and orient their actions to the interests of the collective» ${ }^{35}$.

The bodies clothed as peasant guise portrayed in the pictures are the sensory signs through which the spiritual meaning, which is to say the ideal of sedentary life, take a concrete shape: the individual member becomes part

33 O. Zimmer, "Coping with deviance: Swiss nationhood in the long nineteenth century", Nations and Nationalism, XVII/4, 2011, pp. 756-774.

34 E. Cassirer, "Der Begriff der symbolischen Form im Aufbau der Geisteswissenschaften" (1923), in E. Cassirer, Wesen und Wirkung des Symbolbegriffs, Bruno Cassirer; Oxford 1956, p. 175. See also: T. I. Bayer, Cassirer's Metaphysics of Symbolic Forms, A philosophical Commentary, Yale University Press New Haven 2008, p. 15.

35 «[...] funktioniert der Nationalismus als Motor politischer Prozesse erst dann, wenn sich die einzelnen Mitglieder der beschworenen Gemeinschaft als Teil dieses Ganzen fühlen und ihr Handeln an den Interessen des Kollektivs orientieren». D. Gugerli, D. Speich (hrsg. v.), Topographien der Nation, Politik kartographische Ordnung und Landschaft im 19. Jahrhundert, Chronos Verlag, Zürich 2002, p. 11. 
of the community evoked through self-identification in the portrait onto which the interests of the collective (bourgeois values) have been projected.

In the collective imagination the Swiss national identity coincides with a nation of farmers and shepherds, who love freedom and live in the pristine mountain landscape of the Alps. In the last twenty-years historians have discussed the transnational reframing of national narrative: they speak of this image using two expressions: «Erfundene Schweiz» (invented Switzerland) and «imagologische Basteleien» ${ }^{36}$ (handcrafted imagery), agreeing that it was created at a time in Swiss history - coinciding with the birth of the federal state - when there was a need to spread an ideal of national identity, with which to identify, to ever wider layers of the population. Postcolonial studies contextualize the anthropological debate (i.e. the debate on human nature and its multiple realizations at different times and in different places) of the European colonial period in a landscape of exchanges and influences between colonial and non-colonial powers. A lively filed of postcolonial studies consider history from a dual perspective, i.e. based on a relationship of exchange that doesn't involve just a colonial power and a colony: Switzerland had no colonies, but this does not mean that its history was not influenced by the confrontation with colonial powers. This theoretical framework offers a twofold possibility. Historians are rethinking the formation of Swiss national identity at the time of the emergence of the modern federal state as a colonial state without colonies and having internal colonization as a defining phenomenon ${ }^{37}$. The anthropological debate within

36 G. P. Marchal, A. Mattioli (hrsg. v.), Erfundene Schweiz. Konstruktionen nationaler Identität, Chronos Verlag, Zürich 1992; B. C. Schär, "Bauern und Hirten Reconsidered. Umrisse der 'erfundenen' Schweiz im imperialen Raum”, in P. Purtschert, B. Lüthi, F. Falk (hrsg. v.), Postkoloniale Schweiz. Formen und Folgen eines Kolonialismus ohne Kolonien, Transcript Verlag, Bielefeld 2012, pp. 315-332.

${ }^{37}$ P. Purtschert, H. Fischer-Tiné (ed. by), Colonial Switzerland. Rethinking Colonialism from the Margins, Palgrave Macmillan, New York 2015; J. Osterhammel, Die Verwandlung der Welt. Eine Geschichte des 19. Jahrhunderts, C. H. Beck, Munich 2009; P. Purtschert, F. Falk, B. Lüthi, "Switzerland and Colonialism without Colonies", Interventions, XVIII/2, 2016, pp. 286-302. 
a postcolonial theoretical framework also allows to explain why Durheim's photographic portraits are symbolic manifestations, which activate in the observer-subject the processes of projection and identification. Are the Heimatlose portrayed as "the other»? They are not depicted as "other" in the sense of "foreigner" (Fremde), otherwise they would have been portrayed as they were found before being interned, i.e. half-naked and probably standing in the middle of the road or at the edge of the woods, begging, or hiding (Figure 7).

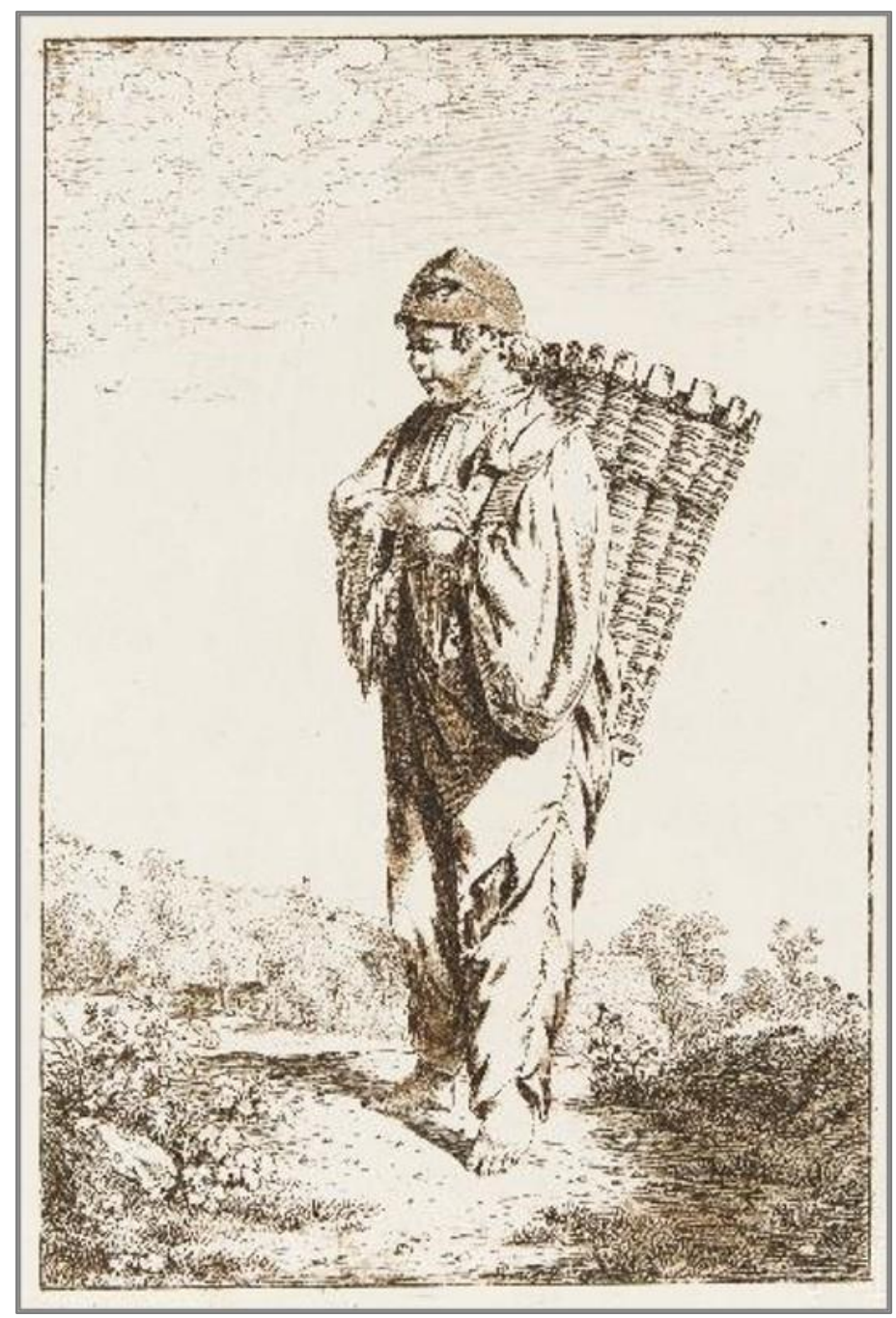

Figure 7: Franz Niklaus König, der Arme, Radierung, 1798, Swiss National Library. 
In the eyes of Swiss elite, the Heimatlose were portrayed as a group of people (peasants and farmers) whose customs they knew, coming into (visual) contact with whom they were pervaded by a sense of familiarity, but at the same time they do not identify directly with them.

In this perspective, however, both of the processes described at the beginning (projection and identification) are present. Because in the figure of the peasant, the urban elite projects ideals of a form of life with which it identifies itself on a theoretical level. These ideals, although shared by the bourgeoisie, are projected outside the urban circle onto the Alpine population, but are always traceable and identifiable in representation, whether literary as in the example of Albrecht von Haller's poem "The Alps" or in visual representation, as in the case of Durheim's portraits of the Heimatlose.

In the eyes of the urban elite, where does this familiarity with the figure of the peasant and farmer come from? What characteristics do peasants embody that interest the urban bourgeoisie?

The constitution of the figure of the peasant, which embodies the ideal of the Swiss national character, has its roots in the disputes within the radical movement of the Swiss intellectual elites of the previous century. Two dialectics were at stake: «the future-oriented vocabulary of social and political improvement and the restoration of the myths of origins» ${ }^{38}$. In this context the Alps were an essential element of patriotic discourse and thought to be «a force capable of shaping national character» ${ }^{39}$. The Alps were not just a background onto which Swiss characters pose: so the interest for geography and landscape has not only to do with the drawing of the national borders. Drawing national borders and describing the geography of it (i.e. maps) implicitly meant to outline the national characters of its inhabitants.

38 O. Zimmer, A Contested Nation: History, Memory and Nationalism in Switzerland, 17611891, Cambridge University Press, Cambridge 2003, p. 41.

${ }^{39}$ Ivi, p. 75. 
The Swiss historian Bernhard C. Schär brings an example from Swiss literature, showing how peasants and shepherds are described in Albrecht von Haller's poem the Alps (1732). Schär points out that Haller uses the Alpines for a discussion that is not conducted with them, but rather by cultured towns about them. Haller provided a representation of alpine realities, which is imaginative and distant from reality; peasants are portrayed only as utopian figures without individual personality, whose purpose is to illustrate what is "different" about them from the cultured circles Haller addresses. Peasants are not characterized as single individuals, but as a group of people with common characters. Peasants are geographically outside the urban space, they are at a certain distance. Such distance and being "other" (i.e. different) does not have a negative connotation, as it is the reason that justifies the position of control of the bourgeoisie ${ }^{40}$.

\section{Conclusion}

Durheim's photographs can thus be read as an attempt by liberal and radical parties represented by Jakob Amiet to re-conceptualize Swiss citizenship in the years following the proclamation of the Swiss Federal State. These efforts took place simultaneously in several areas: the definition of Swiss national identity ran parallel to the definition of national borders through the drawing of maps and topographies ${ }^{41}$; the newly formed Swiss Confederation was characterized by regionalism and was united neither by culture, language, nor faith. The ideals on which the Confederation was based still lacked vibrancy and lived reality. The attempt to identify the radically different bourgeois values in the homeless and at the same time to assimilate

40 See M. L. Pratt (1992): «The systematizing of nature represents not only a European discourse about non-European worlds, but an urban discourse about non-urban worlds, and a lettered, bourgeois discourse about non-lettered, peasant worlds", in B. C. Schär, "Bauern und Hirten Reconsidered. Umrisse der 'erfundenen' Schweiz im imperialen Raum”, cit., p. 321.

${ }^{41}$ D. Gugerli, D. Speich (hrsg. v.), Topographien der Nation, Politik kartographische Ordnung und Landschaft im 19. Jahrhundert, Chronos Verlag, Zürich 2002, pp. 199-201. 
this other was to be welcomed by the Swiss population as one of the concrete and understandable actions to realize the founding values of the nation state. However, this attempt to naturalize itinerants failed, Amiet resigned from his position at the end of 1856: he judged the legislation on the individual branches of federal justice inadequate, partly because of the lack of regulations and the anti-centralist and cantonal tendencies which were becoming more and more apparent in the federal councils on judicial matters and with which he could not find compromise ${ }^{42}$.

The collection of Carl Durheim's photographic portraits are witnesses to an attempt at colonization that was to be carried out with the help of the moral dissuasion ${ }^{43}$ of photographically manipulated identity, which works at once as Allan Sekula defined - «honorific and repressive»44. What remains of this social experiment, then, are visual reminders of the symbolic power of photography in shaping bourgeois self-understanding.

\section{References}

\section{Archival sources}

Schweizerisches Bundesarchiv Bern, Bericht des schweizerischen Bundesrates an die hohe Bundesver- sammlung über seine Geschäftsführung im Jahr 1852, Bundesblatt Nr. 31 von Juli 1853, BB I 1853 II 665.

Schweizerisches Bundesarchiv Bern, CH-BAR E 211000-131205281, Verschiedene Korrespondenzen zu den Photographischen Bilder der Heimatlosen (1852-1853).

${ }^{42}$ T. Meier, R. Wolfensberger, Eine Heimat und doch keine, Heimatlose und Nicht-Sesshaften in der Schweiz (16.-19.Jahrhundert), cit., p. 476.

${ }^{43}$ Schweizerisches Bundesarchiv Bern, Bericht des schweizerischen Bundesrates an die hohe Bundesver- sammlung über seine Geschäftsführung im Jahr 1852, Bundesblatt Nr. 31 von Juli 1853, BB I 1853 II 665, p. 717.

${ }^{44}$ A. Sekula, "The Body and the Archive", cit., p. 6. 


\section{Literature}

ANDERSON, Benedict, Imagined Communities. Reflections on the Origin and the Spread of Nationalism, Verso, London-New York 1991.

BATCHEN, Geoffrey, Photography's Objects, University of New Mexico Press, Albuquerque 1997.

BAYER, Thora Ilin, Cassirer's Metaphysics of Symbolic Forms, A philosophical Commentary, Yale University Press New Haven 2008.

BEESE, Wolfgang, "Zur Geschichte der Polizeifotografie", Kriminalistik, XVIII/11, 1964, pp. 539-550.

BELTING, Hans, Face and Mask: A Double History, en. tr. by T. S. Hansen and A. J. Hansen, Princeton University Press, Princeton-Oxford 2013.

BREDEKAMP, Horst, Theorie des Bildakts, Suhrkamp, Frankfurt am Main 2010.

CARVILLE, Justin, "Photography, Ethnography and Cultural Nationalism in Northern Ireland", in C. Caraffa, T. Serena (ed. by), Photographic Archives and the Idea of Nation, De Gruyter, New York-Berlin, 2015, pp. 17-42.

-, "A Geographic Fact: Photography, Ethnography and History in Ireland", in T. Sheehan (ed by) Photography, History, Difference, Dartmouth College Press, Lebanon New Hampshire 2015, pp. 11-32.

CRARY, Jonathan, Techniques of the Observer: On Vision and Modernity in the Nineteenth Century, MIT Press, Cambridge-London 1990.

DIAMOND, Hugh Welch, Diamond, On the Application of Photography to the Physiognomic and Mental Phenomena of Insanity, Proceedings of the Royal Society of London (1854-1905), 1856. 
DUCHENNE DE BOULOGNE, Guillome-Benjamin, Mécanisme de la physionomie humaine ou analyse électrophysiologique de l'ex-pression des passions, Renouard, Paris 1862.

EDWARDS, Elizabeth, "Photographs: Material Form and the Dynamic Archive", in C. Caraffa (ed. by), Photo Archive and the Photographic Memory of Art History, Deutcher Kunstverlag, Berlin 2001.

—, "Material beings: Objecthood and ethnographic photographs", Visual Studies, XVII/1, 2002, pp. 67-75.

ELLENBOGEN, Josh, Reasoned and Unreasoned Images: The Photography of Bertillon, Galton and Marey, Pennsylvania State University Press, University Park 2012.

GASSER, Martin, MEIER Thomas D., WOLFENSBERGER Rolf (hrsg. v.), Wider das Leugnen und Verstellen, Carl Durheims Fahndungsfotografien von Heimatlosen 1852-1853, Offizin Verlag, Zürich 1998.

GIGER, Bernard, STÄMPFLI Philip, DI FALCO Daniel (hrsg. v.), Carl Durheim - Wie die Fotografie nach Bern kam, Collection Passepartout (7), Burgerbibliothek Bern, Bern 2016.

GUGERLI, David, SPEICH, Daniel (hrsg. v.), Topographien der Nation, Politik kartographische Ordnung und Landschaft im 19. Jahrhundert, Chronos Verlag, Zürich 2002.

HELLEINER, Jane, Irish Travellers. Racism and the Politics of Culture, Toronto University Press, Toronto-Buffalo-London 2000.

HENISH, Heinz, HENISH, Bridget Ann, The Photographic experience 18391914: Images and attitudes, Pennsylvania State University Press, University Park 1994. 
HUGGER, Paul (hrsg. v.), Handbuch der schweizerischen Volkskultur, Offizin, Zürich 1992.

HUONKER, Fahrendes Volk-verfolgt und verfemt, Jenische Lebensläufe, Limmat Verlag, Zürich 1987.

—, "Fremd- und Selbstbilder von "Zigeunern", Jenischen und Heimatlosen in der Schweiz des 19. und 20. Jahrhunderts aus literarischen und anderen Texten", in H. Uerlings, I.-K. Patrut (hrsg. v.), Zigeuner und Nation, Repräsentation - Inklusion - Exklusion, Peter Lang, Frankfurt am Main 2008.

JUNKER, Beat, Geschichte des Kantons Bern Seit 1798, Entstehung Des Demokratischen Volkstaates, Band II, Historischer Verein Des Kantons Bern, Bern, 1990.

JAEGER, Jens, "Police and Forensic Photographic", in R. Lenman, A. Nicholson (ed. by), Oxford Companion to the Photograph, Oxford University Press, Oxford 2005, pp. 507-510.

MARCHAL, Guy P., MATTIOLI A. (hrsg. v.), Erfundene Schweiz. Konstruktionen nationaler Identität, Chronos Verlag, Zürich 1992.

MAXWELL, Anne, Picture Imperfect: Photography and Eugenics, 1870-1940, Sussex Academic Press, Brighton 2008.

MEIER, Thomas, WOLFENSBERGER, Rolf, Eine Heimat und doch keine, Heimatlose und Nicht-Sesshaften in der Schweiz (16.-19.Jahrhundert), Chronos Verlag, Zürich 1998.

MOSER, Gabrielle, Projecting Citizenship: Photography and belonging in the British Empire, Pennsylvania State University Press, University Park 2019 . 
OSTERHAMMEL, Jürgen, Die Verwandlung der Welt. Eine Geschichte des 19. Jahrhunderts, C. H. Beck, Munich 2009.

PURTSCHERT, Patricia, FISCHER-TINÉ Harald (ed.), Colonial Switzerland. Rethinking Colonialism from the Margins, Palgrave Macmillan, New York 2015.

PURTSCHERT, Patricia, FALK Francesca, LÜTHI Barbara, "Switzerland and Colonialism without Colonies”, Interventions, XVIII/2, 2016, pp. 286-302.

PURTSCHERT, Patricia, LÜTHI Barbara, FALK Francesca (hrsg. v.), Postkoloniale Schweiz. Formen und Folgen eines Kolonialismus ohne Kolonien, Transcript Verlag, Bielefeld 2012.

PEARL, Sharonna, About Faces: physiognomy in Nineteenth-Century Britain, Harvard University Press, Cambridge Massachusetts 2010.

PINNEY, Christopher, Photography and Anthropology, Reaktion Books, London 2011.

PHÉLINE, Christian, L’image accusatrice, Laplume: ACCP, France 1985.

REGENER, Susanne, "Ausgegrenzt. Die optische Inventalisierung des Menschen in Polizeiwesen und in der Psychiatrie", Fotogeschichte, XXXVIII, 1991, pp. 23-38.

RYAN, James R., Picturing Empire: Photography and the Visualization of British Empire, University of Chicago Press, Chicago 1998.

SEKULA, Allan, "The body and the Archive", October, XXXIX, 1986, pp. 3-64.

TAGG, John, The burden of representation, Essays on Photographies and Histories, The University of Massachusetts Press, Amherst 1988. 
TILLMANNS, Urs, Geschichte der Fotografie: ein Jahrhundert prägt ein Medium, Frauenfeld, 1981.

ZIMMER, Oliver, A Contested Nation: History, Memory and Nationalism in Switzerland, 1761- 1891, Cambridge University Press, Cambridge 2003.

—, "Coping with deviance: Swiss nationhood in the long nineteenth century", Nations and Nationalism, XVII/4, 2011.

\section{Biographical note}

Sara Romani is a $\mathrm{PhD}$ candidate at the Kunsthistorisches Institut of the Universitaet $\mathrm{zu}$ Koeln. After receiving her Bachelor of Arts at the Brera Academy of Fine Arts in Milan, she moved to Boston to pursue graduate studies: she graduated from Massachusetts College of Art and Design, with a Master of Fine Arts degree in Photography. At Massachusetts College of Art and Design she was also lecturer and research assistant for the Photography Department. 